(C) 2020 by the Arizona Board of Regents on behalf of the University of Arizona. This is an Open Access article, distributed under the terms of the Creative Commons Attribution licence (http://creativecommons. org/licenses/by/4.0/), which permits unrestricted re-use, distribution, and reproduction in any medium, provided the original work is properly cited.

\title{
SHCal20 SOUTHERN HEMISPHERE CALIBRATION, 0-55,000 YEARS CAL BP
}

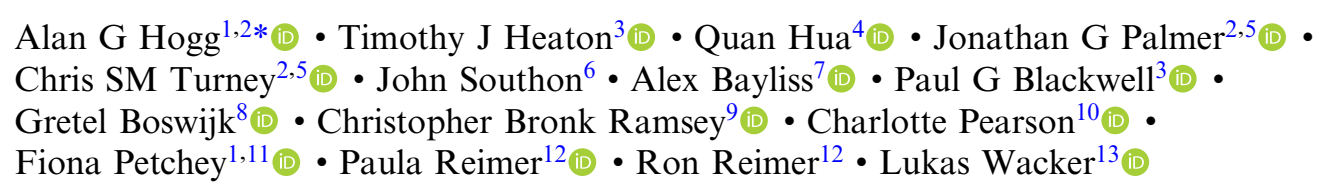

${ }^{1}$ Waikato Radiocarbon Laboratory, University of Waikato, Private Bag 3105, Hamilton, New Zealand

${ }^{2}$ ARC Centre of Excellence for Australian Biodiversity and Heritage, School of Biological, Earth and Environmental Sciences, University of New South Wales, Sydney, NSW 2052, Australia

${ }^{3}$ School of Mathematics and Statistics, University of Sheffield, Sheffield S3 7RH, UK

${ }^{4}$ Australian Nuclear Science and Technology Organisation, Locked Bag 2001, Kirrawee DC, NSW 2232, Australia

${ }^{5}$ Chronos ${ }^{14}$ Carbon-Cycle Facility and Changing Earth, University of New South Wales, Sydney, NSW 2052, Australia

${ }^{6}$ Department of Earth System Science, University of California, Irvine, CA 92697-3100, USA

${ }^{7}$ Historic England, 4th Floor, Cannon Bridge House, 25 Dowgate Hill, London, EC4R 2YA, UK

${ }^{8}$ School of Environment, University of Auckland, New Zealand

${ }^{9}$ Research Laboratory for Archaeology and the History of Art, University of Oxford, 1 South Parks Road, Oxford OX1 3TG, UK

${ }^{10}$ The Laboratory of Tree-Ring Research, University of Arizona, Tucson, AZ 85721-0400, USA

${ }^{11}$ ARC Centre of Excellence for Australian Biodiversity and Heritage, College of Arts, Society and Education, James Cook University, PO Box 6811, Cairns, Queensland 4870, Australia

${ }^{12}$ Centre for Climate, the Environment \& Chronology $\left({ }^{14} \mathrm{CHRONO}\right)$, School of Natural and Built Environment, Queen's University Belfast, Belfast BT7 1NN, UK

${ }^{13}$ Laboratory of Ion Beam Physics, HPK, H29, Otto-Stern-Weg 5, CH-8093 Zürich, Switzerland

\begin{abstract}
Early researchers of radiocarbon levels in Southern Hemisphere tree rings identified a variable NorthSouth hemispheric offset, necessitating construction of a separate radiocarbon calibration curve for the South. We present here SHCal20, a revised calibration curve from 0-55,000 cal BP, based upon SHCal13 and fortified by the addition of 14 new tree-ring data sets in the 2140-0, 3520-3453, 3608-3590 and 13,140-11,375 cal BP time intervals. We detail the statistical approaches used for curve construction and present recommendations for the use of the Northern Hemisphere curve (IntCal20), the Southern Hemisphere curve (SHCal20) and suggest where application of an equal mixture of the curves might be more appropriate. Using our Bayesian spline with errorsin-variables methodology, and based upon a comparison of Southern Hemisphere tree-ring data compared with contemporaneous Northern Hemisphere data, we estimate the mean Southern Hemisphere offset to be $36 \pm 27^{14} \mathrm{C}$ yrs older.
\end{abstract}

KEYWORDS: carbon cycle, Inter-Tropical Convergence Zone (ITCZ), interhemispheric gradient (IHG), North-South hemispheric offset, Southern Ocean, tropical and sub-tropical radiocarbon calibration.

\section{HISTORY OF SOUTHERN HEMISPHERE CALIBRATION}

The conversion of terrestrial radiocarbon $\left({ }^{14} \mathrm{C}\right)$ ages into calendar time requires a calibration curve that accurately reflects past atmospheric ${ }^{14} \mathrm{C}$ levels. Tree rings offer unsurpassed accuracy and resolution if derived from a replicated tree-ring chronology and if adequately pretreated, so that the dated fraction faithfully captures atmospheric ${ }^{14} \mathrm{C}$ concentrations at the time of growth, unaffected by variable lignin contents or species-specific differences (McCormac et al. 1998a).

Whilst a major focus of the radiocarbon community has been the calibration of the timescale, early work soon demonstrated there was an offset in atmospheric ${ }^{14} \mathrm{C}$ concentrations between the hemispheres. Some of the earliest measurements of Southern Hemisphere (SH) tree rings

\footnotetext{
*Corresponding author. Email: alan.hogg@waikato.ac.nz.
} 
indicated depleted ${ }^{14} \mathrm{C}$ levels with $\mathrm{SH}$ tree rings giving older values compared to contemporaneous tree rings from the Northern Hemisphere $(\mathrm{NH})$. This was probably a result of higher sea-air ${ }^{14} \mathrm{CO}_{2}$ flux from the larger expanse of $\mathrm{SH}$ oceans (Lerman et al. 1970; Rodgers et al. 2011). Lerman et al. (1969, 1970) measured a North-South (N-S) hemispheric offset of $\sim 36-42{ }^{14} \mathrm{C}$ yrs and Vogel et al. $(1986,1993)$ measured additional Netherlands/South Africa sample pairs and obtained a value of $41 \pm 5{ }^{14} \mathrm{C} \mathrm{yrs}{ }^{\dagger}$. Vogel et al. (1993) recommended using this constant to create a calibration curve for SH mid-latitudes, based upon the data of Stuiver and Pearson (1993) for the NH.

Subsequently, paired decadal measurements made from contemporaneous British oak (Quercus petraea) and New Zealand (NZ) cedar (Libocedrus bidwillii) or silver pine (Manoao colensoi) tree rings from 1000-0 cal BP by Queen's University Belfast (identifier UB) and Waikato University (identifier $\mathrm{Wk}$ ), showed there were differences between the structural forms of the radiocarbon calibration curves for each hemisphere. They demonstrated that the N-S offset was not constant but varied with time, with a periodicity of approximately $130 \mathrm{cal} \mathrm{yrs}$, and amplitudes ranging from $8-80{ }^{14} \mathrm{C}$ yrs (McCormac et al. 1998a, 1998b; Hogg et al. 2002). Building on this work, McCormac et al. (2002) published the first iteration of SHCal (SHCa102) covering the interval 1000-100 cal BP, compiled from data sets derived from NZ (Wk, UB; McCormac et al. 1998a, 1998b; Hogg et al. 2002), Chile (Quaternary Isotope Lab, identifier QL; Stuiver and Braziunus 1998), Tasmania (QL; Stuiver and Braziunus 1998) and South Africa (Pretoria, identifier Pta; Vogel et al. 1993). The combined SH data sets showed a mean offset of $41 \pm 14{ }^{14} \mathrm{C}$ yrs for the interval 1000-100 cal BP and in the absence of additional measured SH data, the authors recommended this value be applied to IntCal98 (Stuiver et al. 1998) for the period outside this range. The $\mathrm{SH}$ calibration was extended to 11,000 cal BP by McCormac et al. (2004) using the same random walk model and parameters as for IntCal04 (Reimer et al. 2004, Buck and Blackwell 2004). SHCal04 contained the SHCal02 data sets and IntCal04 data with a modeled offset beyond the range of the $\mathrm{SH}$ measurements. The modeled offset ranged from 55 to $58{ }^{14} \mathrm{C}$ yrs with uncertainties increasing from $\pm 7.9{ }^{14} \mathrm{C}$ yrs at $1000 \mathrm{cal} \mathrm{BP}$ to $\pm 25{ }^{14} \mathrm{C}$ yrs at 11,000 cal BP.

In parallel with the above studies, Hua et al. (2004a) obtained 16 decadal sample pairs (Australian Nuclear Science \& Technology Organisation, identifier OZ) from Tasmania (Huon pine, Lagarostrobos franklinii) and Thailand (Pinus merkusii) for the interval 325-175 cal BP to investigate the ${ }^{14} \mathrm{C}$ content of the atmosphere sampled by tropical trees. The mean offset between Tasmania (older) and Thailand was $30 \pm 8{ }^{14} \mathrm{C}$ yrs. Further back in time, Hua et al. (2009) analysed 134 tree-ring samples (OZ) from four Younger Dryas (YD)-age Tasmanian Huon pine subfossil logs (SRT-779, -781, -782, -783) extracted from alluvial sediments along Stanley River in Northwest Tasmania (Australia). Ring-width measurements, supplemented by ${ }^{14} \mathrm{C}$ wiggle-matching against IntCal04 data (utilizing a $40{ }^{14} \mathrm{C}$-yrs constant N-S offset) produced a 617-yrs-long floating chronology, spanning the calendar age interval of 12,679-12,072 ( \pm 11) cal BP. Zimmerman et al. (2010) obtained new decadal measurements (Center for AMS, identifier CAMS) from a Huon pine tree-ring series for the interval 2115-855 cal BP. However, Hogg et al. (2011) obtained data (Wk) for a similar interval from NZ kauri (Agathis australis: 2145-955 cal BP) tree-ring series (Boswijk et al. 2014) and suggested some of the equivalent Huon pine data had underestimated uncertainties, with some data points (1205-1075 cal BP) that could be too

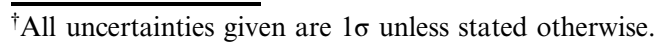


young. This was confirmed by re-measurement of nine Huon pine decadal samples (Wk) from the interval 1175-1095 cal BP (Hogg et al. 2013a).

Building on the above studies and new datasets from the NH, the 2013 iteration of the SH curve was extended from 0 to 50,000 cal BP (Hogg et al. 2013b). The resulting SHCal13 was a compilation of the SH data sets described above, and based upon IntCal13 data (Reimer et al. 2013), corrected for a N-S offset, beyond the range of the measured data sets. The calibration curve was constructed using a Markov Chain Monte Carlo (MCMC) implementation of the random walk model, with transitional regions where the variance depends upon the measured ( $\mathrm{SH}$ data) and modeled (IntCal13 data adjusted by the N-S offset) data sets (Heaton et al. 2009; Niu et al. 2013).

There are some aspects of SHCal13 that have potentially important implications for SHCal20:

1. The value of $129 \pm 14 \mathrm{BP}$ from Pretoria (identifier Pta) for $100 \mathrm{cal} \mathrm{BP}(1850 \mathrm{CE})$ that was used in SHCal04 and SHCal13 is incorrect. The correct value of $155 \pm 11$ BP (Hogg et al. 2019) is used in SHCal20.

2. Of the four YD-age subfossil Huon pine ${ }^{14} \mathrm{C}$ data sets in Hua et al. (2009), only SRT-779 agreed closely with contemporaneous YD-age subfossil New Zealand kauri (see further details below). For this reason, the other three Huon pine data sets (SRT-781, -782, and -783) have been omitted from SHCal20.

\section{NEW SOUTHERN HEMISPHERE DATA SETS}

\subsection{High-resolution data relating to the $\mathbf{7 7 4}$ and 993 CE cosmic events}

Miyake et al. $(2012,2013)$ discovered two large and rapid increases in atmospheric ${ }^{14} \mathrm{C}$ concentration $\left(\Delta^{14} \mathrm{C}\right)$ from Japanese tree rings dated to $1176 / 5$ cal $\mathrm{BP}(774 / 5 \mathrm{CE})$ and 957/6 cal BP (993/4 CE). Corresponding anomalous ${ }^{10} \mathrm{Be}$ and ${ }^{36} \mathrm{Cl}$ events recorded in ice cores (Mekhaldi et al. 2015) suggest extreme fluxes from high-energy solar particles were responsible. The $\mathrm{NH}$ expression of these events has been detailed in several studies (see Büntgen et al. 2018 and references therein). Güttler et al. (2015) measured $\Delta^{14} \mathrm{C}$ levels in NZ kauri, showing their global nature. Annual or biennial $\mathrm{SH} \Delta^{14} \mathrm{C}$ data from seven tree-ring series, six relating to the $774 \mathrm{CE}$ event (four from NZ and one each from Chile and Tasmania) and one to the $993 \mathrm{CE}$ event (NZ)_Table 1 are available from the Büntgen et al. (2018) study (ETH/AMS facility, identifier ETH, alpha-cellulose). They calculated offsets to contemporaneous $\mathrm{NH}$ data of $\sim 30{ }^{14} \mathrm{C}$ yrs (in terms of $\Delta{ }^{14} \mathrm{C}$, these offsets equate to $4.0 \pm 0.4 \%$ in $774 \mathrm{CE}$ and $3.5 \pm 0.7 \%$ in $993 \mathrm{CE}$ ). These data are available from the SHCal database (http://intcal.org/shcal20/- datasets 9-1, 9-2, 9-3, 9-4, 9-5, 9-6). The high-resolution SH data compare well with existing SH decadal data (Figures 1A and 1B).

\subsection{New 450-0 cal BP data sets}

Four new data sets in the interval 450-0 cal BP have been included in SHCal20 (see Table 2). Data set 3-7 contains $22 \mathrm{Wk}$ decadal solvent-extracted alpha-cellulose high precision radiometric analyses spanning the interval 1725-1935 CE and first given in McCormac et al. (1998a). This group of analyses was accidentally omitted from SHCal04 and SHCal13 but is included in SHCal20. 
Table 1 Summary of new high-resolution SH tree-ring chronologies/data sets including the time span, block interval (number of yrs [i.e. rings] per analysis) and total number of analyses (N). From Büntgen et al. (2018).

\begin{tabular}{|c|c|c|c|c|c|}
\hline Series ID $^{\mathrm{a}}$ & Location & Species/Lat.,long. & Time span & $\begin{array}{l}\text { Block } \\
\text { interval }\end{array}$ & $\mathrm{N}$ \\
\hline $\begin{array}{l}9-1 . \\
\text { DAR01 } \\
\text { (HAR010a) }\end{array}$ & Dargaville, NZ & $\begin{array}{l}\text { Agathis australis } \\
35^{\circ} 55^{\prime} \mathrm{S}, 173^{\circ} 48^{\prime} \mathrm{E}\end{array}$ & $\begin{array}{c}950-960 \mathrm{CE} \\
1000-990 \mathrm{cal} \mathrm{BP}\end{array}$ & $0.5-1$ & $\overline{24}$ \\
\hline $\begin{array}{l}9-1 . \\
\text { DAR01 } \\
\text { (HAR010a) }\end{array}$ & Dargaville, NZ & $\begin{array}{l}\text { Agathis australis } \\
35^{\circ} 55^{\prime} \mathrm{S}, 173^{\circ} 48^{\prime} \mathrm{E}\end{array}$ & $\begin{array}{c}770-780 \mathrm{CE} \\
1180-1170 \mathrm{cal} \\
\text { BP }\end{array}$ & $0.5-1$ & 24 \\
\hline $\begin{array}{l}9-2 . \\
\text { DAR06 } \\
\text { (HAL025a) }\end{array}$ & Dargaville, NZ & $\begin{array}{l}\text { Agathis australis } \\
35^{\circ} 55^{\prime} \mathrm{S}, 173^{\circ} 48^{\prime} \mathrm{E}\end{array}$ & $\begin{array}{c}770-780 \mathrm{CE} \\
1180-1170 \mathrm{cal} \\
\text { BP }\end{array}$ & 1 & 11 \\
\hline $\begin{array}{l}9-3 . \\
\text { DAR07 } \\
\text { (HAL025b) }\end{array}$ & Dargaville, NZ & $\begin{array}{l}\text { Agathis australis } \\
35^{\circ} 55^{\prime} \mathrm{S}, 173^{\circ} 48^{\prime} \mathrm{E}\end{array}$ & $\begin{array}{c}1770-780 \mathrm{CE} \\
1180-1170 \mathrm{cal} \\
\text { BP }\end{array}$ & 1 & 11 \\
\hline $\begin{array}{l}9-4 . \\
\text { NEW01 } \\
\text { (LC122) }\end{array}$ & Moana, NZ & $\begin{array}{l}\text { Manoao colensoi } \\
42^{\circ} 30^{\prime} \mathrm{S}, 171^{\circ} 38^{\prime} \mathrm{E}\end{array}$ & $\begin{array}{c}770-780 \mathrm{CE} \\
1180-1170 \mathrm{cal} \\
\text { BP }\end{array}$ & 1 & 11 \\
\hline $\begin{array}{l}9-5 . \\
\text { PAT02 } \\
\text { (ELA1-2) }\end{array}$ & El Asiento, Chile & $\begin{array}{l}\text { Austrocedrus chilensis } \\
32^{\circ} 39^{\prime} \mathrm{S}, 70^{\circ} 49^{\prime} \mathrm{W}\end{array}$ & $\begin{array}{c}770-780 \mathrm{CE} \\
1180-1170 \mathrm{cal} \\
\text { BP }\end{array}$ & 1 & 11 \\
\hline $\begin{array}{l}9-6 . \\
\text { TAS01 } \\
\text { (SRT554A) }\end{array}$ & $\begin{array}{l}\text { Stanley R., } \\
\text { Tasmania }\end{array}$ & $\begin{array}{l}\text { Lagarostrobos } \\
\quad \text { franklinii } \\
41^{\circ} 45^{\prime} \mathrm{S}, 145^{\circ} 14^{\prime} \mathrm{E}\end{array}$ & $\begin{array}{c}770-780 \mathrm{CE} \\
1180-1170 \mathrm{cal} \\
\text { BP }\end{array}$ & 1 & 11 \\
\hline
\end{tabular}

aSeries numbers 9-1 to 9-6 correspond with "Set No." and "Division" in SHCal database (http://intcal.org/shcal20).

Data sets 3-8 and 3-9 are composed from Wk decadal alpha-cellulose AMS analyses spanning the interval 1705-1945 CE and published in Turney et al. (2016). This publication also contained complementary data from Lake Tay (Western Australia) and Campbell Island (NZ). The Lake Tay data set was not considered for SHCal20 because of suspicions that the very high resin content characteristic of the Callitris columellaris trees may have resulted in translocation of ${ }^{14} \mathrm{C}$ across ring boundaries. The Campbell Island Dracophyllum longifolium data, also omitted, was systematically older than contemporaneous measurements from mid-latitude SH locations, probably as a result of its high latitude Southern Ocean location. See Hogg et al. (2019) for a discussion of both the Lake Tay and Campbell Island data sets. Data set 3-10 contains duplicated Wk five-ring alpha-cellulose AMS analyses spanning the interval 1652-1827 CE and published in Hogg et al. (2019).

Hogg et al. (2019) presented a new Bayesian spline method for calibration curve construction (see below) and tested it on $11 \mathrm{SH}$ data sets. The four new data sets presented here had relative offsets from the mean of $\sim+6$ to $-6{ }^{14} \mathrm{C}$ yrs indicating their suitability for inclusion in SHCal20.

\subsection{New 3608-3453 cal BP data sets}

Two new single tree ring data sets in the interval 3608-3453 cal BP have been included in SHCal20 (see Table 3). Data set 7-1 contains 16 University of Arizona AMS Facility 


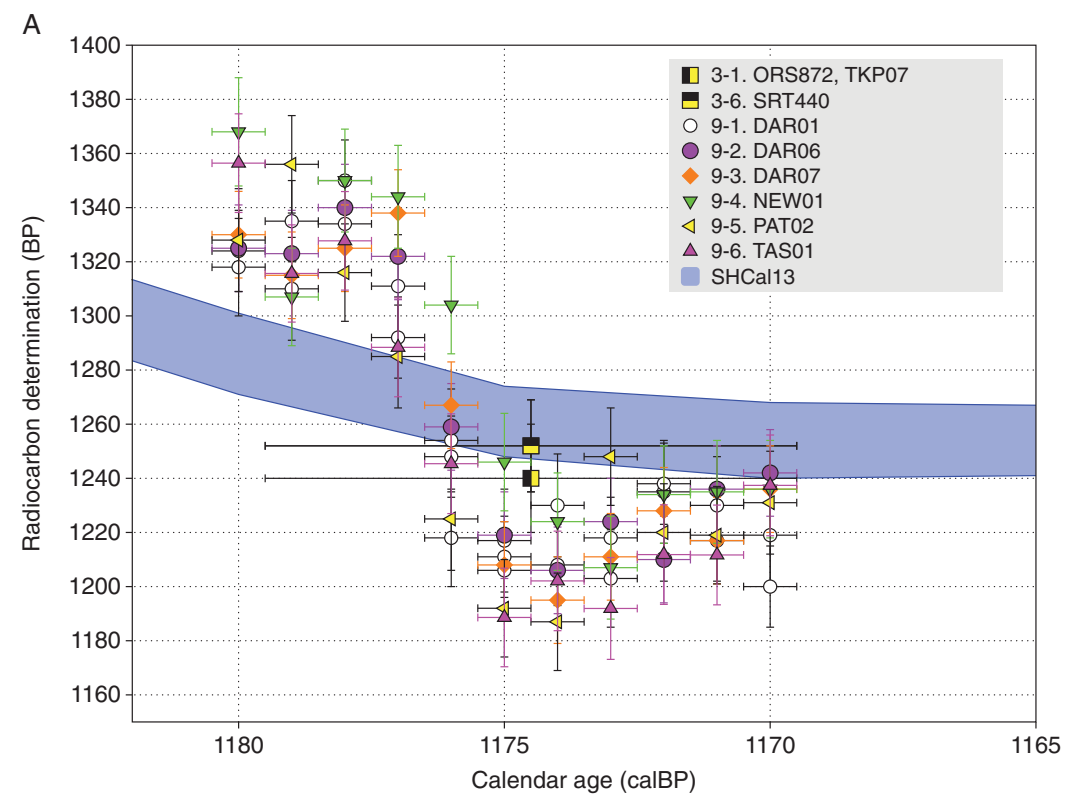

Figure 1A Southern Hemisphere tree-ring ${ }^{14} \mathrm{C}$ data relating to the $774 \mathrm{CE}$ event. Treering series include: 3-1 (Wk, Manoao colensoi, Oroko Swamp, NZ and Libocedrus bidwillii, Takapari Forest Park, NZ); 3-6 (Wk, Lagarostrobos franklinii, Stanley River, Tasmania, Australia); 9-1, 9-2, 9-3 (ETH, Agathis australis, Dargaville, NZ); 9-4 (ETH, Manoao colensoi, Moana, NZ); 9-5 (ETH, Austrocedrus chilensis, El Asiento, Chile); 9-6 (ETH, Lagarostrobos franklinii, Stanley River, Tasmania, Australia).

analyses (identifier AA) spanning the interval 3608-3590 cal BP and 65 AA analyses spanning 3520-3453 cal BP. Pearson et al. (2020 in this issue) compare a sub-set of these data with single year measurements (AA) from Irish oak and North American bristlecone pine, and provide additional fine scale information on the N-S offset during this period.

The two new AA data sets are plotted with SHCal13 in Figure 2.

\subsection{New Younger Dryas-age measurements}

Hogg et al. (2016a, 2016b) presented a floating ${ }^{14} \mathrm{C}$ chronology containing 1022 measurements from NZ kauri trees spanning the interval $\sim 11,285-9990{ }^{14} \mathrm{C}$ yrs BP (mean $1 \sigma$ uncertainty $=$ $\pm 28{ }^{14} \mathrm{C}$ yrs). The kauri trees were located in Northland, at Towai (series name 8-1, CRW003) and Dargaville (series name $8-2$, FIN11). The Towai decadal samples $\left(\sim 11,285-10,070{ }^{14} \mathrm{C} \mathrm{BP}\right)$ were derived from a well replicated and securely cross-matched tree-ring chronology (1451 rings, 91 radial strips derived from 37 trees with an average cross-correlation coefficient between all series of 0.71 , Palmer et al. 2016). The 778 analyses were determined principally by University of California, Irvine (identifier UCI, holo-cellulose, AMS), Wk (alphacellulose, high precision liquid scintillation spectroscopy) and Oxford University (identifier OxA, alpha-cellulose, AMS) with a few additional analyses by ETH (alpha-cellulose, AMS) and University of Heidelberg (identifier Hd, holo-cellulose, Gas Proportional Counting - GPC).

The Dargaville decadal samples $\left(\sim 10,305-9990{ }^{14} \mathrm{C}\right.$ yrs BP) were obtained from a single tree (FIN11, two measured radii, estimated 533 rings), with the 244 analyses undertaken by UCI 


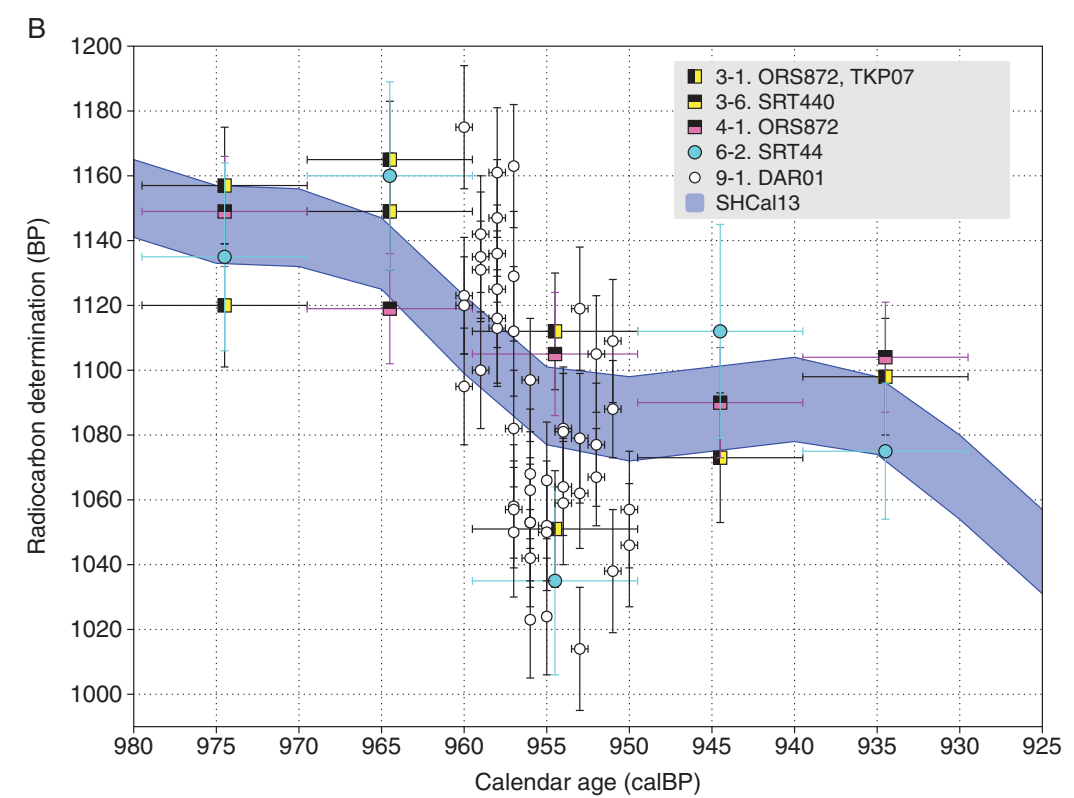

Figure 1B Southern Hemisphere tree-ring ${ }^{14} \mathrm{C}$ data relating to the $993 \mathrm{CE}$ event. Treering series include: 3-1 (Wk, Manoao colensoi, Oroko Swamp, NZ and Libocedrus bidwillii, Takapari Forest Park, NZ); 3-6 (Wk, Lagarostrobos franklinii, Stanley River, Tasmania, Australia); 4-1 (UB, Manoao colensoi, Oroko Swamp, NZ); 6-2 (CAMS, Lagarostrobos franklinii, Stanley River, Tasmania, Australia); 9-1 (ETH, Agathis australis, Dargaville, NZ).

(holo-cellulose, AMS) and Wk (alpha-cellulose, predominantly high precision liquid scintillation spectroscopy).

The Towai and Dargaville ${ }^{14} \mathrm{C}$ data sets were wiggle-matched against contemporaneous $\mathrm{NH}$ data contained within IntCal13, being careful to avoid aberrant sections of the curve (see Hogg et al. 2016a for details), returning calendar age estimates of $\sim 13,134-11,695$ cal BP (Towai) and 11,870-11,367 cal BP (Dargaville). More recent unpublished higher resolution NH pine (Pinus sylvestris) and NZ kauri measurements by ETH have indicated that the Towai kauri YD ${ }^{14} \mathrm{C}$ data set should be shifted towards older ages by $10 \pm 3$ cal yrs resulting in a final calendar age range of $\sim 13,144-11,705 \pm 3$ cal BP (Sookdeo et al. 2019 in this issue, 2020). This shift also affects the Dargaville series, with an adjusted calendar age range of $\sim 11,880-11,377 \pm 5$ cal BP. Both Towai and Dargaville data sets have been included in SHCal20 on the basis of a recent decision made by the IntCal Working Group to accept wiggle-matched data from pre-Holocene floating trees.

The four YD-age Huon pine samples analysed by Hua et al. (2009) were compared with the Towai kauri series by Hogg et al. (2016a). The four trees could not be cross-matched by dendrochronology alone and required additional linking by ${ }^{14} \mathrm{C}$ wiggle-matching (Hua et al., 2009); of the four, only SRT-779 agreed closely with the well-replicated Towai chronology $\left(n=24 ; A c o m b=126.4 \% ; A n=14.4 \% . \chi^{2}\right.$-test: $d f=23 T=15.018(5 \% 35.173)$ see Hogg et al. 2016a for model details) and is retained for SHCal20. For more information on the chronological issues associated with some of the YD-age Huon pine ${ }^{14} \mathrm{C}$ series and ultimately their exclusion from SHCal20, please refer to Hogg et al. (2016a, 2016b). 
Table 2 Summary of new 450-0 cal BP SH tree-ring chronologies/data sets showing the time span, block interval (number of yrs [i.e. rings] per analysis) and total number of analyses (N). Dating methods: HPLSC—high precision liquid scintillation counting; AMS—accelerator mass spectrometry.

\begin{tabular}{|c|c|c|c|c|c|c|}
\hline ID & Location & Species/Lat.,long. & $\begin{array}{r}\text { Time span } \\
\text { (mid-points) }\end{array}$ & Block interval & $\mathrm{N}$ & Notes \\
\hline$\overline{3-7 .}$ & Hihitahi Forest & Libocedrus bidwillii & $1725-1935 \mathrm{CE}$ & 10 & 22 & McCormac et al. (1998a) \\
\hline H4702 & Park, NZ & $39^{\circ} 32^{\prime} \mathrm{S}, 175^{\circ} 44^{\prime}$ & $224.5-14.5$ cal BP & & & $\begin{array}{l}\text { HPLSC } \\
\text { solv. extr. }{ }^{+} \alpha \text {-cellulose }\end{array}$ \\
\hline $3-8$. & Hihitahi Forest & Libocedrus bidwillii & 1705-1945 CE & 10 & 45 & Turney et al. (2016) \\
\hline H4702, ТKР144\# & Park, NZ & $39^{\circ} 32^{\prime} \mathrm{S}, 175^{\circ} 44^{\prime}$ & $244.5-4.5$ cal BP & & & $\begin{array}{l}\text { AMS } \\
\alpha \text {-cellulose }\end{array}$ \\
\hline 3-9. DBY $225^{\wedge}$ & $\begin{array}{l}\text { Doughboy Bay, } \\
\text { Stewart Isl., } \\
\text { NZ }\end{array}$ & $\begin{array}{l}\text { Halocarpus biformis } \\
47^{\circ} 01^{\prime} \mathrm{S}, 167^{\circ} 42^{\prime} \mathrm{E}\end{array}$ & $\begin{array}{r}1705-1945 \mathrm{CE} \\
244.5-4.5 \text { cal BP }\end{array}$ & 10 & 45 & $\begin{array}{l}\text { Turney et al. (2016) } \\
\text { AMS } \\
\alpha \text {-cellulose }\end{array}$ \\
\hline 3-10. SPC002 & Auckland, NZ & Agathis australis & $\begin{array}{l}1652-1827 \mathrm{CE} \\
298-123 \text { cal BP }\end{array}$ & 5 & 72 & $\begin{array}{l}\text { Hogg et al. }(2017,2019) \\
\text { AMS }^{\uparrow} \\
\text { solv. extr. }{ }^{+} \alpha \text { - cellulose }\end{array}$ \\
\hline
\end{tabular}

^1915-1945 decades given preliminary multiple solvent (acetone) extractions.

Tduplicate analyses.

\#1931-1950 decades from Takapari FP (4004’S, 17559’E)

+ solv. extr. $=$ solvent (acetone) extracted.

${ }^{*}$ kauri derived from the upper North Island of NZ but exact geographic location unknown. 
Table 3 Summary of new 3608-3453 cal BP SH tree-ring chronologies/data sets showing the time span, block interval (number of yrs [i.e. rings] per analysis) and total number of analyses $(\mathrm{N})$.

\begin{tabular}{|c|c|c|c|c|c|c|}
\hline ID & Location & Species/Lat.,long. & $\begin{array}{l}\text { Time span } \\
\text { (mid-points) }\end{array}$ & $\begin{array}{l}\text { Block } \\
\text { interval }\end{array}$ & $\mathrm{N}$ & Notes \\
\hline $\begin{array}{l}7-1 . \\
\text { GIB102 }\end{array}$ & $\begin{array}{l}\text { Gibsons } \\
\text { Farm } \\
\text { Dargaville, } \\
\text { NZ }\end{array}$ & $\begin{array}{l}\text { Agathis australis } \\
35^{\circ} 54^{\prime} \mathrm{S}, 173^{\circ} 48^{\prime} \mathrm{E}\end{array}$ & $\begin{array}{c}3608-3590 \mathrm{cal} \\
\text { BP } \\
3520-3453 \mathrm{cal} \\
\text { BP }\end{array}$ & $\begin{array}{l}1 \\
1\end{array}$ & $\begin{array}{l}16 \\
65\end{array}$ & $\begin{array}{l}\text { Pearson et al. } \\
\text { ( } 2020 \text { in this } \\
\text { issue), AMS, } \\
\text { holo-cellulose }\end{array}$ \\
\hline
\end{tabular}

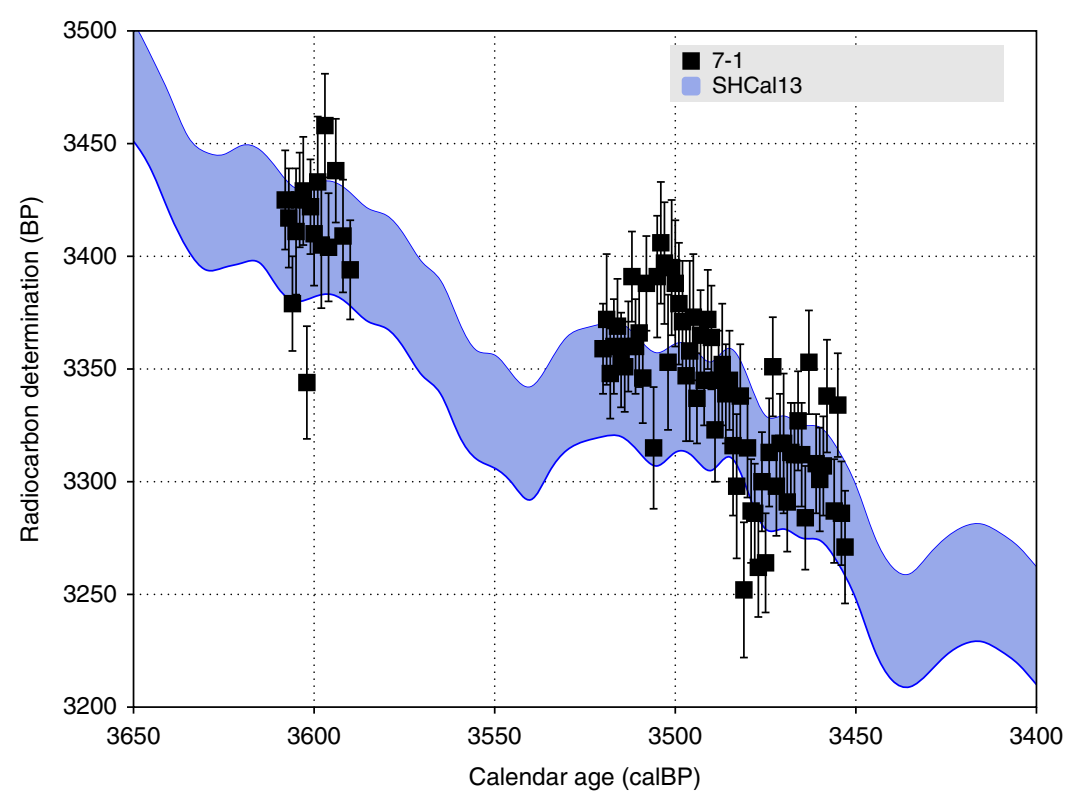

Figure 2 New single-ring ${ }^{14} \mathrm{C}$ data sets (7-1) in the interval $3608-3453$ cal BP. Series 7-1 (AA, Agathis australis, Dargaville NZ).

The YD-age data sets included in SHCal20 are shown graphically in Figure 3. The new YD measurements refine the shape of the $\mathrm{SH}$ atmospheric curve from $\sim 13,100-11,400$ cal BP.

Hogg et al. (2016a) showed that the ${ }^{14} \mathrm{C}$ calibration curve IntCal13, and as a consequence SHCal13, was clearly too young from $\sim 12,200-11,900$ cal BP. This time interval had previously been occupied by an incorrectly linked larch tree-ring series from Ollon, Switzerland (Ollon505, also termed VOD505, Hogg et al. 2013c). They also showed that the YD-B chronology was incorrectly linked by dendrochronology to NH Holocene data and this caused the $\sim 10,400 \mathrm{BP}{ }^{14} \mathrm{C}$ plateau in IntCal13 and SHCal13 to be $\sim 5$ decades too short, thus shifting the two ${ }^{14} \mathrm{C}$ peaks seen at around 12,500 cal BP towards older calendar ages by about 50 cal yrs. This finding has recently been confirmed with new dendrochronological and ${ }^{14} \mathrm{C}$ measurements on NH trees (Sookdeo et al. 2019, 2020). 


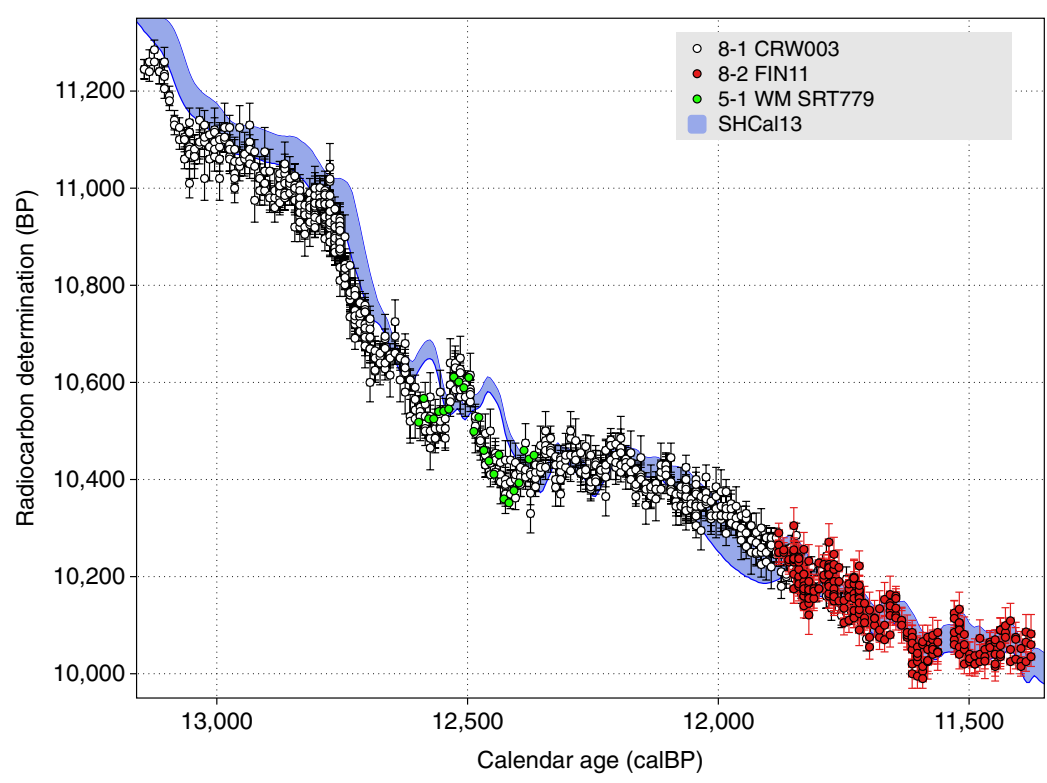

Figure 3 Southern Hemisphere YD-age tree-ring ${ }^{14} \mathrm{C}$ data sets. Tree-ring series include: 8-1 (UCI, Wk and OxA, Agathis australis, Towai, NZ; 8-2 (UCI and Wk, Agathis australis, Dargaville NZ); 5-1 (OZ, Lagarostrobos franklinii, Stanley River, Tasmania, Australia).

\section{CALIBRATION CURVE CONSTRUCTION}

We would ideally wish to create a complete, annually resolved, SHCal20 calibration curve based solely upon direct SH observations and without requiring any modeling assumptions about the nature of the N-S hemispheric offset to be made. Such a curve would be entirely independent from the NH IntCal20 curve (Reimer et al. 2020 in this issue). With our new and existing datasets this is achievable in four distinct time periods: those covering the $\mathrm{SH}$ trees dated by dendrochronology of approximately 2140-0, 3520-3453, and 3608-3590 cal $\mathrm{BP}$; and that covering the floating SH trees of approximately 13,140-11,375 cal BP. However outside these time periods we are lacking direct $\mathrm{SH}$ observations, and so in order to create the SHCal curve, we will need to include information from the corresponding NH IntCal20 curve. This requires us to make a simple statistical model of the N-S atmospheric radiocarbon offset to transfer information from the $\mathrm{NH}$ data.

We aim to provide a construction method where, for the four time periods listed above with dense SH data, the SHCal20 curve is the exact curve one would obtain using only that SH data. These SH-data-based sections of curve are then used to learn about the nature of the N-S hemispheric offset and extrapolate to extend SHCal20 over the complete $0-55$ cal kBP (thousands of calibrated years before present) time range. The construction process is shown in Figure 4. The concept is similar to that used for SHCall3 although the new SHCal20 methodology incorporates and estimates the N-S offset, and hence the final SH calibration curve, more rigorously.

\subsection{Creating a curve where we have SH observations}

We commence by creating a preliminary SH calibration curve based only on the available SH data using the same Bayesian spline with errors-in-variables methodology of IntCal20; see 

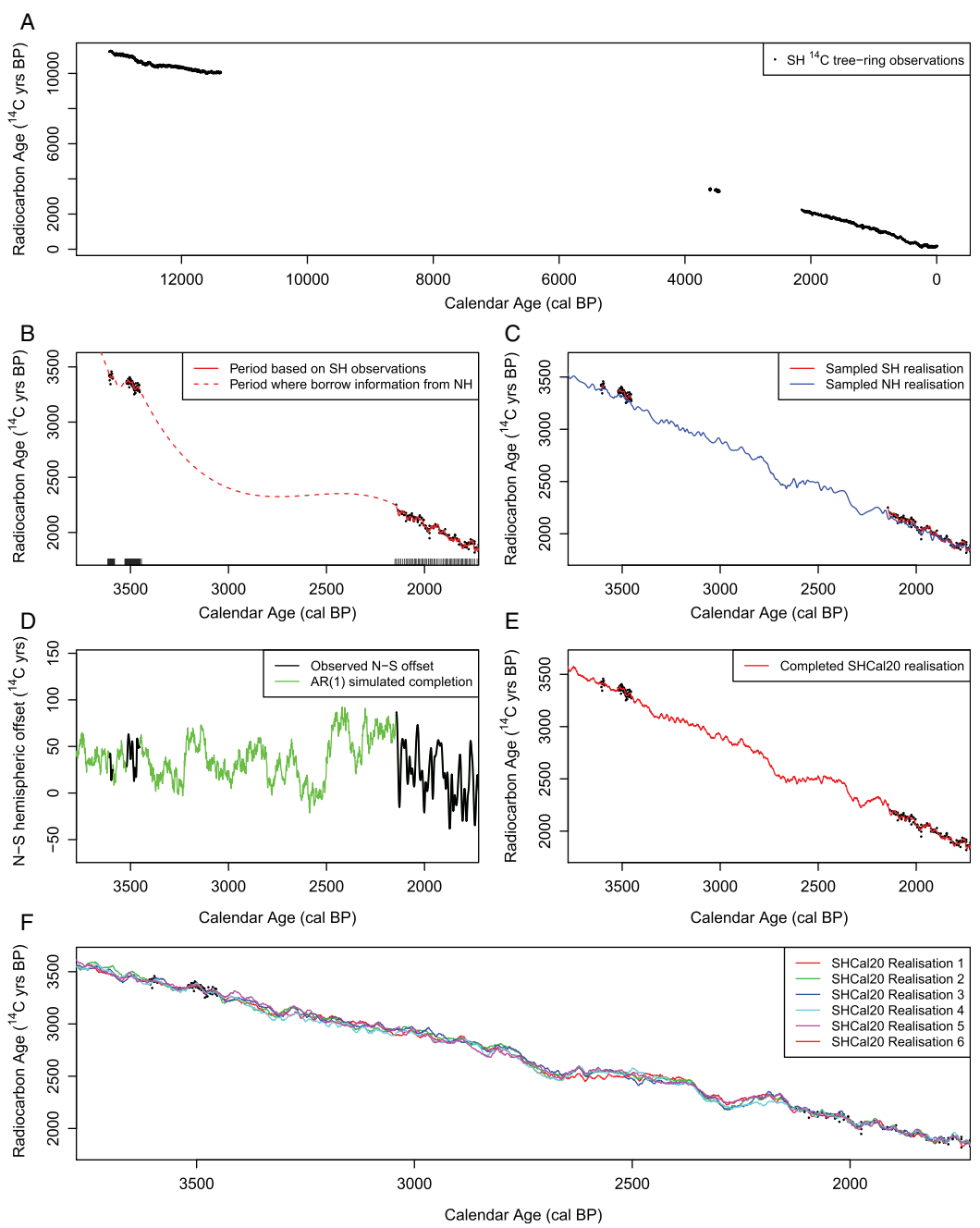

Figure 4 A step-by-step illustration of SHCal20 curve construction. Panel A: The SH ${ }^{14} \mathrm{C}$ observations covering the four distinct time periods where direct measurements are available. We initially fit a Bayesian spline to this observed $\mathrm{SH}{ }^{14} \mathrm{C}$ data. In the periods where we have sufficient direct SH observations, this spline fit is SHCal20; outside these times, in periods where we not have direct $\mathrm{SH}$ observations and this initial spline is not informative, we instead base SHCal20 on importing information from the $\mathrm{NH}$ by modeling the N-S hemispheric offset. Panel B: A zoomed-in section with a posterior realization of the initial spline fitted to the $\mathrm{SH}{ }^{14} \mathrm{C}$ observations, the rug indicates the knot locations. Where we do not have direct $\mathrm{SH}$ observations this initial fitted spline is deleted (red dashed line) leaving an incomplete part SH-realization (red solid line). Panel $\mathrm{C}$ : The incomplete part SH-realization (red solid line) is paired with a complete 0-55 cal kBP NH IntCal20 spline realization (blue solid line). Panel D: In periods where we have direct $\mathrm{SH}$ data the offset between the selected part $\mathrm{SH}$ - and complete $\mathrm{NH}$ - spline realizations is calculated (black solid line) and extended to the missing periods (green solid line) by modeling, conditional on the black calculated values, as an AR(1) process. Panel E: The completed, AR(1)-simulated, offset is added back to the NH-realization providing a completed 0-55 cal kBP SH-realization (red solid line). Due to construction, in periods where $\mathrm{SH}$ data is available this completed $\mathrm{SH}$-realization will be identical to the initial part SH-realization. Panel F: This process is repeated with multiple (part $\mathrm{SH}$ - and complete NH-) spline realizations to provide an ensemble of AR(1)-completed $\mathrm{SH}$-realizations which are summarized to provide the SHCal20 curve. (Please see electronic version for color figures.) 


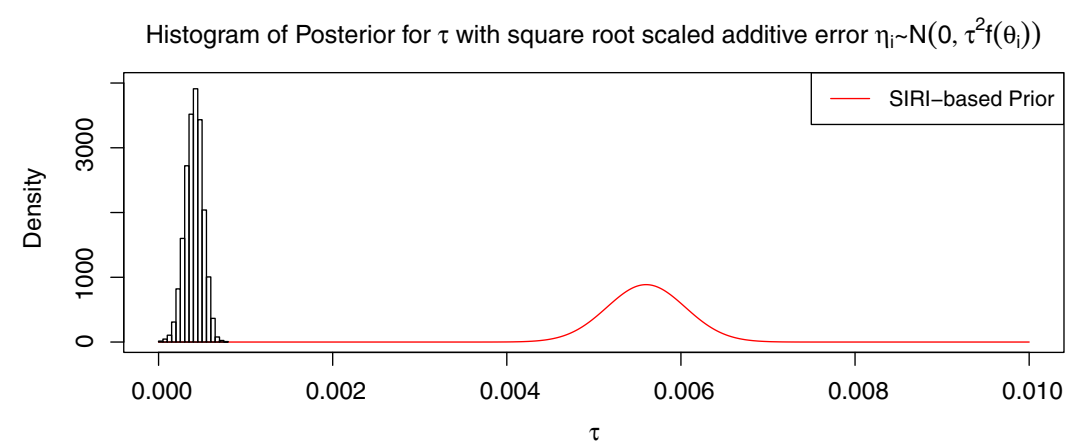

Figure 5 Histogram of the posterior for $\tau$, the level of over-dispersion in the SHCal20 data. We model $F_{i}$, the observed value of $\mathrm{F}^{14} \mathrm{C}$ in (annual) datum $i$ with calendar age $\theta_{i}$, as $F_{i}=f\left(\theta_{i}\right)+\epsilon_{i}+\eta_{i}$. Here $f\left(\theta_{i}\right)$ is the underlying atmospheric $\mathrm{F}^{14} \mathrm{C}$ level at $\theta_{i}$ cal $\mathrm{BP}$ in the SH; $\epsilon_{i} \sim N\left(0, \sigma_{i}^{2}\right)$ the laboratory reported uncertainty; and $\eta_{i} \sim N\left(0, \tau^{2} f\left(\theta_{i}\right)\right)$ the over-dispersion used to model any potential further additional variability seen in the SHCal20 data. Note that, as for IntCal20, our model for this over-dispersion/additional variability scales with $\sqrt{ } f\left(\theta_{i}\right)$, the square root of $\mathrm{F}^{14} \mathrm{C}$. We also show the SIRI-based prior in red. As expected, this SIRI-based prior on the level of over-dispersion is larger than our posterior due to the screening criteria for SHCal20 data. The posterior estimate is dominated by the SHCal20 data rather than the prior.

Heaton et al. (2020 in this issue) for further details. For the three distinct time periods covered by the observed SH trees dated by dendrochronology (approximately 2140-0, 3520-3453, 3608-3590 cal BP) we select the same knots for our spline, both in terms of number and location, as used in IntCal20. This includes the specific, additional knots placed around 774/5 CE and 993/4 CE used to enable representation of the rapid Miyake "cosmic" events (Miyake et al. 2012, 2013). This matched knot selection with the NH IntCal20 curve enables equitable comparisons on the N-S hemispheric offset to be made and, since the density of the $\mathrm{SH}$ data is lower than the density of the data from the $\mathrm{NH}$, is sufficient for us to capture the detail within the available $\mathrm{SH}{ }^{14} \mathrm{C}$ observations. For the floating $\mathrm{SH}$ tree rings (approximately 13,140-11,375 cal BP) we use the same number of knots as in the corresponding section of the IntCal20 curve but space them evenly over the interval. Such a placement allows the Bayesian method to explore the exact calendar location of these floating trees equitably - an uneven knot spacing introduces bias as the method will tend to align the trees so that wiggles in the underlying levels of ${ }^{14} \mathrm{C}$ fit with higher knot density (Heaton et al. 2020 in this issue). Outside these time periods, where no SH data are present, we reduce the number of knots in our spline.

Repeat observations on same-sample material are combined as for IntCal20. We also place the same prior on the additive over-dispersion, obtained from the Sixth International Radiocarbon Intercomparison (SIRI, Scott et al. 2017), as used for IntCal20 (see Heaton et al. 2020 in this issue, for details on how this prior was constructed). This over-dispersion attempts to identify and quantify any potential additional variability in ${ }^{14} \mathrm{C}$ determinations beyond the laboratoryquoted uncertainty (e.g. growing season, intra-hemispheric regional effects, species) to ensure we do not obtain an over-precise calibration curve. Our SIRI-based prior, together with the posterior we obtain from the SHCal20 data, are shown in Figure 5.

The MCMC Bayesian spline curve fitting process was run for 50,000 iterations with the first 25,000 discarded as "burn-in" (for an introduction to Bayesian analysis and MCMC, see 
Gelman et al. 2013). Due to the predominantly Gibbs update steps, and after a visual assessment of various individual parameters, this length of run was felt to be sufficient to achieve convergence. The output was then thinned, saving only every 10th iteration, to reduce auto-correlation in the fitted location of the floating trees.

The described approach provides curve estimates in these four time intervals based only upon the $\mathrm{SH}$ data in such a way that still allows us to share information on ${ }^{14} \mathrm{C}$ variability over time (as represented by the spline's smoothing parameter) between the disjoint intervals and jointly estimate the level of over-dispersion. After thinning, we obtain from this MCMC 2500 posterior part-realizations (so called since they only cover these four disjoint time intervals) of the $\mathrm{SH}$ atmosphere (Figure 4B) together with corresponding posterior estimates for the over-dispersion in ${ }^{14} \mathrm{C}$ within the $\mathrm{SH}$. We call these sections of the curve SH-data-based.

Outside of these four time intervals however, the above approach does not work since we do not have $\mathrm{SH}$ data on which to base an estimate. To create a complete $\mathrm{SH}$ curve from $0-55$ cal $\mathrm{kBP}$ we need to rely upon importing information from the NH curve based upon a model for the N-S offset. However, we wish to do this in such a way that ensures that, in these four specific intervals, our final SHCal20 curve still corresponds to these SH-data-based estimates.

\subsection{Extending the SH curve by modeling}

We model the evolution of the N-S offset over time as a first-order autoregressive (AR(1)) process. This time-varying process models $X_{t}$, the N-S offset at calendar age $t$, as linearly dependent upon the size of the offset in the previous year, with the addition of a stochastic/ random component. Specifically,

$$
X_{t}=\mu+\phi\left(X_{t-1}-\mu\right)+\epsilon_{t}
$$

where the $\epsilon_{t}$ are considered independent and identically distributed from a $N\left(0, \sigma_{e}^{2}\right)$ distribution. Here $\mu$ denotes the mean N-S offset and the parameter $\phi$ encapsulates the N-S offset's dependence over time. We aim to learn about this offset based upon both our SH-databased curve and our corresponding IntCal20 curve. We can then extrapolate the NH curve accordingly in the time periods where SH data are lacking.

Each of the $2500 \mathrm{SH}$-data-based part-realizations is paired with a randomly drawn $\mathrm{NH}$ curve realization from the IntCal20 posterior (Figure 4C). Unlike the SH part-realizations, each of these $\mathrm{NH}$ realizations extend from $0-55 \mathrm{cal} \mathrm{kBP}$. In the $\mathrm{SH}$-data sections, the offset between the $\mathrm{NH}$ and $\mathrm{SH}$ realization is calculated and an AR(1) process is fitted to these observed values using maximum likelihood. We then form, conditional on the observed offset in the SH-data sections, predictions for the N-S offset for the calendar ages outside the range of the SH-data covering the complete $0-55 \mathrm{cal} \mathrm{kBP}$ period (Figure 4D). To create a full SH-realization this offset is then added to the NH realization (Figure 4E).

This approach provides 2500 complete SH-realizations (Figure 4F) which, in the SH-databased regions, are identical to their corresponding part $\mathrm{SH}$-realization. Outside they transition smoothly to an offset version of their paired NH realization, with the size of that offset realization dependent and determined according to our best, maximum likelihood, estimate. 


\subsection{Adding in over-dispersion and creating predictive intervals}

Finally we add back in our SH-data-based measure of over-dispersion to these 2500 complete $\mathrm{SH}$-realizations to create predictive intervals for the complete SHCal20 curve. This overdispersion aims to assess any potential additional ${ }^{14} \mathrm{C}$ variability, seen within observed $\mathrm{SH}$ tree-ring determinations with identical calendar ages, beyond that quoted by the laboratories. Such additional ${ }^{14} \mathrm{C}$ variability is to be expected since laboratories are only able to quantify those elements within their control and could occur as a consequence of intra-hemispheric regional differences in ${ }^{14} \mathrm{C}$ levels; between-tree, species or growing season differences; or inter-laboratory differences. By incorporating this additional variability into predictive intervals on the calibration curve we aim to ensure we do not provide overly precise calendar age estimates. For more details see Heaton et al. (2020 in this issue).

We note that the level of over-dispersion estimated from the SHCal20 data (shown in Figure 5) is smaller than that within the NH (Heaton et al. 2020 in this issue: Figure 5). This could be due to the smaller range of potential sources of additional variability within the collated SHCal20 tree rings when compared to the $\mathrm{NH}$ IntCal20 data. The $\mathrm{SH}{ }^{14} \mathrm{C}$ tree-ring measurements generally have fewer overlapping trees in any time period, come from a smaller number of laboratories, cover a smaller number of tree species, and arise from a smaller set of locations. However, alternatively it might be that there is less additional variation in ${ }^{14} \mathrm{C}$ levels within the $\mathrm{SH}$, perhaps due to reduced regional effects. As a consequence of this reduced over-dispersion with the $\mathrm{SH}$ tree rings, as we extend past $\sim 40$ cal $\mathrm{kBP}$ the published SHCal20 curve has slightly narrower predictive intervals than IntCal20.

\subsection{Model robustness: An alternative approach with sampling importance resampling (SIR)}

The above approach of randomly pairing $\mathrm{NH}$ and $\mathrm{SH}$ curve realizations does not fully incorporate all the information one could extract from the offset model, as it does not take into account possible dependence between the uncertainties in the two curves. Specifically, we may end up with pairings whereby the calculated offset does not agree well with an AR(1) process in which case we have the potential to overestimate the uncertainty in the predicted offset and consequently the final SHCal20 curve.

To investigate if this was a genuine concern, we therefore also considered an alternative, more statistically rigorous sampling importance resampling (SIR) approach, whereby each SH partrealization was compared to all of the $2500 \mathrm{NH}$ realizations stored for IntCal20. The maximised likelihood of the observed offset between the SH part-realization and each of these NH realizations was calculated under the $\mathrm{AR}(1)$ model to provide an importance weight for each match of the $\mathrm{SH}$ part-realization to all the $\mathrm{NH}$ realizations. The specific $\mathrm{NH}$ realization with which to pair the $\mathrm{SH}$ part-realization was then randomly chosen according to these importance weights. The offset was then extrapolated as for the random pairing but now with a pair that best approximates an $\operatorname{AR}(1)$ process. As for the random pairing, this SIR approach ensures that the complete SHCal20 realizations agree with their corresponding part-realization.

This SIR approach was however extremely slow to run since, unlike the random pairing, it required calculation of the maximised likelihood for all possible combinations of $\mathrm{SH}$ and NH realizations. Further, and more significantly, this SIR approach gave a very small effective sample size with the same few NH realizations being chosen repeatedly. In the older pre-Holocene time periods where the underlying NH data have considerable calendar 
Mean of Hemispheric Offset

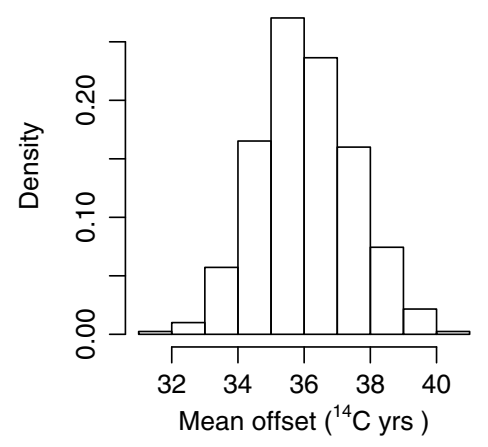

SD of Hemispheric Offset

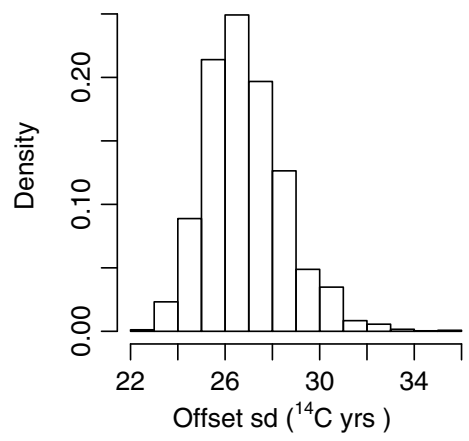

Figure 6 Histograms of the estimated means and standard deviations (sd) of the $\mathrm{AR}(1)$ processes used to model the N-S hemispheric offset.

age uncertainty and a large posterior sample is required to accurately represent the curve, the SIR approach consequently failed. The value of the $\mathrm{NH}$ calibration curve in these older time periods is almost independent of its value in the calendar periods (e.g. 2000-0 cal BP) where the weighting was performed, and the offset observed. As a result of this independence, during these older periods where we have no direct SH data, the SH curve should simply be a constant offset from IntCal20 since for these older times we are reliant upon the NH curve and our offset model to provide the SH estimate. This was not the case for the SIR based estimate. The random pairing approach did however create an $\mathrm{SH}$ curve estimate with a constant offset from IntCal20 as we extend back beyond our observed SH data and towards 55 cal kBP indicating that random pairing worked appropriately for these older time periods.

Further, in regions where the underlying NH curve is based on trees dated by dendrochronology and a small posterior sample is sufficient to reliably summarize the curve, the SIR approach was indistinguishable from the random pairing method. This suggests the random pairing approach is robust and does not introduce additional uncertainty, providing confidence in the reconstruction.

Finally, we note that it would be possible to construct both the NH and SH curves simultaneously, combining data from both hemispheres and a model for the offset into a joint curve creation. This is a consideration for future curve updates although it would raise the issue of potential asymmetry (which hemisphere should be considered offset?) and that, even in regions where SH data were dense, the SH curve would be influenced by the NH data. Such an integrated MCMC approach may also re-introduce some of the mixing difficulties seen in the random walk approach of IntCal13 making curve estimation much more computationally intensive.

\subsection{Value of the N-S offset}

Each of the 2500 pairings of $\mathrm{NH}$ and $\mathrm{SH}$ curve realizations provides a slightly different estimate of the N-S offset. This will result in us estimating 2500 different AR(1) processes each with its own mean and standard deviations. In Figure 6, we present the estimated mean offsets and standard deviation over time for all these 2500 realized offsets. Based 
upon these 2500 paired curves we estimate the mean $\mathrm{N}-\mathrm{S}$ offset to be $36{ }^{14} \mathrm{C}$ yrs with a standard deviation of $27{ }^{14} \mathrm{C}$ yrs (i.e. $36 \pm 27{ }^{14} \mathrm{C}$ yrs).

For time intervals based upon IntCal20 data adjusted for the N-S hemispheric offset, we recommend that readers also consult the complementary IntCal20 paper (Reimer et al. 2020 in this issue) which details the differences between IntCal20 and IntCal13.

A comparison of the SHCal13 and SHCal20 curves without the underlying data for clarity is given in Supplementary Material (Figure S1).

\section{SHCal20 CALIBRATION FOR TROPICAL AND SUBTROPICAL REGIONS}

\subsection{The Inter-Tropical Convergence Zone (ITCZ) and inter-hemispheric air mass mixing}

The youngest portions of IntCal20 and SHCal20 curves are based on tree rings from temperate latitudes of each hemisphere. An obvious question is which calibration curve should be used in the tropics and subtropics given no long tree-ring ${ }^{14} \mathrm{C}$ records for these regions are currently available.

Several studies suggest that atmospheric ${ }^{14} \mathrm{C}$ over tropical and subtropical regions could be influenced by north-south air-mass mixing as a result of monsoon circulation. Hua et al. (2004a, 2004b) and Hua and Barbetti (2007) discussed influences of SH air masses on atmospheric ${ }^{14} \mathrm{C}$ over northern tropical and subtropical regions during the pre-bomb and post-bomb periods. Similarly, Hua et al. (2012) reported monsoonal influences of NH air masses on atmospheric ${ }^{14} \mathrm{C}$ over a southern tropical island (latitude $5^{\circ} \mathrm{S}$ ) in Indonesia during the post-bomb period. The use of either IntCal20 or SHCal20 curve for regions which are influenced by monsoon circulation, might be therefore inappropriate, and a mixed curve accounting for north-south air-mass mixing can be used for these regions. This approach is similar to that for tropical South America proposed by Marsh et al. (2018).

Monsoon circulation can result in air-mass mixing and high precipitation (McGregor and Nieuwolt 1998; Zhang and Wang 2008), and in several monsoon regions the bands of highest summer precipitation approximately follow the position of the ITCZ (Figure 7). However, climate model simulations and reanalysis data indicate that not all areas experiencing high precipitation are strongly influenced by air masses from the opposing hemisphere. In particular, reanalysis data for the past 3 decades (Figure 7) shows that the intrusion of $\mathrm{NH}$ air into the southeast trending South Pacific Convergence Zone (SPCZ) is sharply truncated (but see Section 4.2). We therefore consider it more prudent to use wind data and the seasonal ITCZ positions rather than precipitation to estimate the zonal boundaries of the areas in which IntCal20, SHCal20 and a mixed curve are used.

We therefore recommend the use of (i) IntCal20 for areas north of the ITCZ in June-August (dashed lines in Figure 7) which receive NH air masses all year round, (ii) SHCal20 for areas south of ITCZ in December-February (dotted lines in Figure 7) which see SH air masses all year round, and (iii) a mixed curve for areas between the two seasonal ITCZ positions shown in Figure 7, which receive northern air masses in December-February and southern air masses in June-August.

The degree of north-south air-mass mixing for the mixed curve is another issue. For vegetation, which grows almost all year round, the degree of air-mass mixing should be 50\%:50\% (northern:southern air masses). For seasonal vegetation, the degree of air-mass mixing 

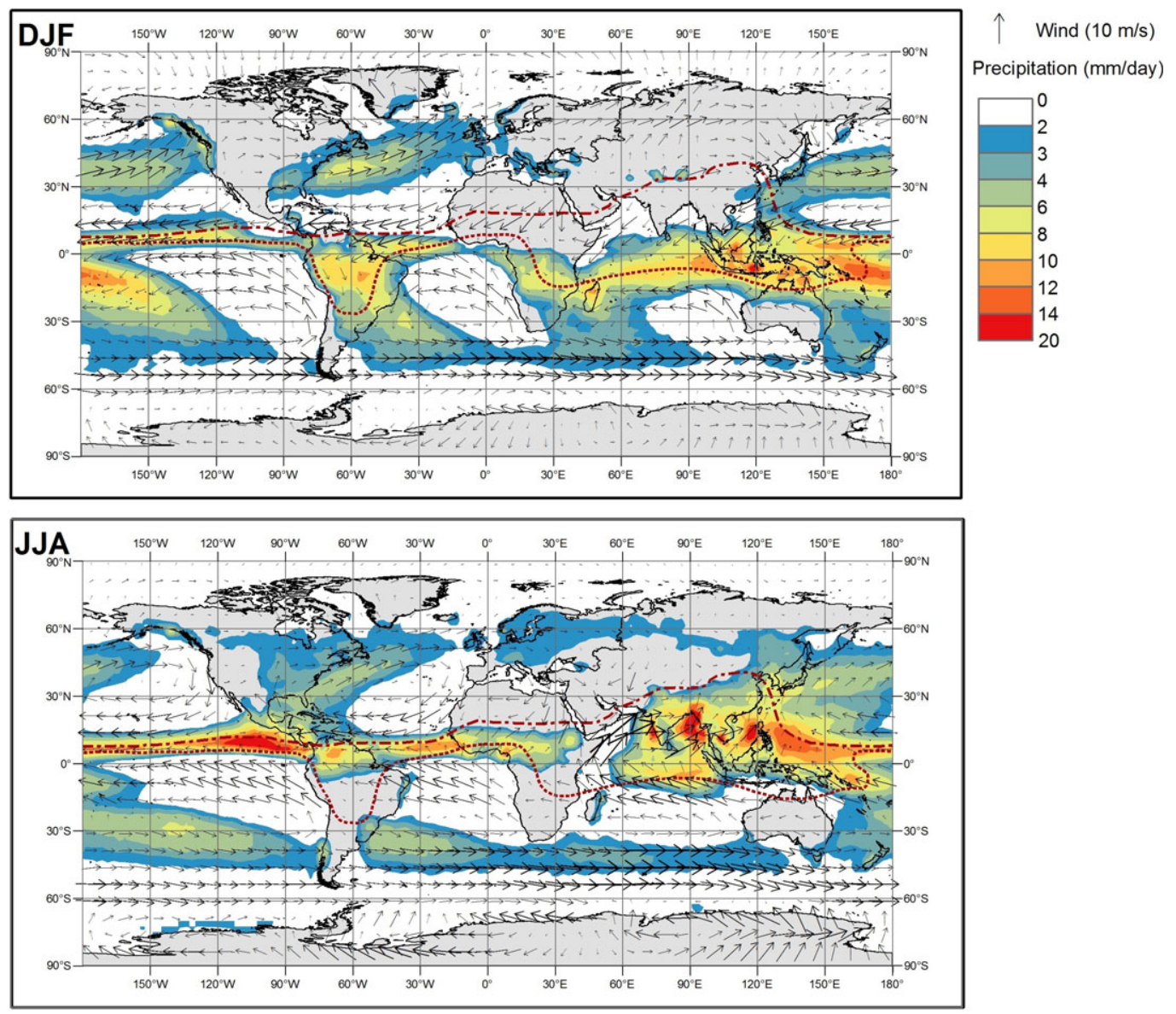

Figure 7 World map showing means of winds (1981-2010) and precipitation (1979-2018) at 925 hPa for two different periods: December-February (top panel) and June-August (bottom panel). These data are derived from the NCEP reanalysis wind (https://www.esrl.noaa.gov/psd/data/gridded/data.ncep.reanalysis.derived.pressure.html) and the CMAP precipitation (Xie and Arkin 1997), respectively. Dotted and dashed lines represent the ITCZ during December-February and June-August, respectively.

might be different than the above value. However, Hua and Barbetti (2007) estimated a $52 \pm 13 \%$ contribution of southern air masses to northern tropical and subtropical regions influenced by monsoons during the boreal summer months, which was based on atmospheric and tree-ring ${ }^{14} \mathrm{C}$ data during the bomb-peak period. We thus recommend a simple approach with $50 \%: 50 \%$ of north-south air-mass mixing for the mixed curve, and age calibration using that curve can be easily carried out using the "Mix_curve" command in OxCal program (Bronk Ramsey, 2009) or selected as a curve option in CALIB 8.2 (Stuiver et al. 2020).

\subsection{Past ITCZ variations}

As the mean seasonal positions of the ITCZ and the strength of monsoon circulation change at different timescales (inter-annual, decadal, centennial, etc.; e.g., Haug et al. 2001), the boundaries of the mixed-curved areas in the past can be different from those shown in Figure 7, which are based on the modern meteorological data. At least for the remote past, 
the use of IntCal, SHCal or a mixed curve for a particular region in the tropics and subtropics becomes less critical for many studies when the maximum ${ }^{14} \mathrm{C}$ offsets of these curves, which are the N-S offsets of $36 \pm 27{ }^{14} \mathrm{C}$ yrs (based upon our estimates in Section 3.5) are negligible compared to the ages of the events to be dated.

However, this may not be the case for researchers studying human expansion over short time scales. For example, Goodwin et al. (2014) have reconstructed Pacific climate and in particular wind field patterns associated with changing El Niño and La Niña events, over the last $~ 1000$ yrs, using a general circulation climate model extensively calibrated with paleoclimate data. Their model showed large variations on decadal and longer timescales in the mixing of NH air into the South Pacific via the SPCZ, dependent on the state of the Pacific Decadal Oscillation and the decadal-scale predominance of El Niño vs La Niña events, with minimal mixing in some bi-decades and a mixed region extending as far as $30^{\circ} \mathrm{S}$ across most of the Pacific in others.

It seems highly likely that similarly detailed wind field reconstructions in other areas will also show significant variations in the past boundaries of the zone covered by the movement of the ITCZ. Until new tree-ring ${ }^{14} \mathrm{C}$ data sets are created from within the tropics and subtropics, only approximations for the boundaries of the mixed region and the regional balance of northern and southern air masses within it are possible, and researchers wishing to calibrate radiocarbon data from these regions should be mindful of these limitations. Future research efforts should focus on ${ }^{14} \mathrm{C}$ measurement on tree rings from these areas in order to construct proper calibration curves for these regions, and to gain a better understanding of regional ${ }^{14} \mathrm{C}$ offsets and their temporal variations.

\section{HIGH SOUTHERN LATITUDES}

De Pol-Holz et al. (2017) have suggested that an additional high latitude SH region should be distinguished, as the region south of the peak intensity of the Southern Westerly Winds $\left(\sim 50^{\circ} \mathrm{S}\right)$ is influenced by the release of old carbon from the Southern Ocean due to upwelling and air-sea gas exchange. Turney et al. (2016) and Hogg et al. (2019) also found lower ${ }^{14} \mathrm{C}$ levels from Campbell Island $\left(53^{\circ} \mathrm{S}\right)$ tree rings, supporting this finding. We have not implemented such a feature in this version of SHCal, but researchers calibrating measurements from the subantarctic SH should be aware of the likelihood that a small and likely time-varying offset exists. As more calibration data from southern South America and subantarctic islands in the Southern Ocean become available, we anticipate that a separate high latitude Region 1 will likely be incorporated into future versions of SHCal.

\section{ACKNOWLEDGMENTS}

TJ Heaton is supported by a Leverhulme Trust Fellowship RF-2019-14019, "Improving the Measurement of Time Using Radiocarbon". We would like to thank Stuart Hankin and Jagoda Crawford for the preparation of Figure 7, and Duncan Christie and Ed Cook for providing additional information on the tree ring dating of PAT02 (dataset 9-5) and TAS01 (dataset 9.6) respectively.

\section{SUPPLEMENTARY MATERIAL}

To view supplementary material for this article, please visit https://doi.org/10.1017/RDC.2020.59 


\section{REFERENCES}

Boswijk G, Fowler A, Palmer J, Fenwick P, Hogg A, Lorrey A, Wunder J. 2014. The late Holocene kauri chronology: assessing the potential of a 4500-yrs record for palaeoclimate reconstruction. Quaternary Science Reviews 90:128-142.

Bronk Ramsey CB. 2009. Bayesian analysis of radiocarbon dates. Radiocarbon 51:337-360.

Buck CE, Blackwell PG. 2004. Formal statistical models for estimating radiocarbon calibration curves. Radiocarbon 46: 1093-1102.

Büntgen U, Wacker L, Galván JD, Arnold S, Arseneault D, Baillie M, Beer J, Bernabei M, Bleicher N, Boswijk G, et al. 2018. Tree rings reveal globally coherent signature of cosmogenic radiocarbon events in 774 and 993 CE. Nature Communications 9:3605. doi: 10.1038/s41467018-06036-0.

De Pol-Holz R, Santos GM, Ancapichun S, Southon J, Collado S, Aravena JC, Christie D, Lara D, Le Quesne C, Creasman PP, Reimer P. 2017. Radiocarbon content in annual tree-rings from western South America: The "Bomb" period 1950-2015 AD. 14th International AMS Conference, University of Ottawa, Canada, August 14-18 2017 (abstr.)

Gelman A, Carlin JB, Stern HS, Rubin DB. 2013. Bayesian data analysis. 3rd ed. Chapman and Hall.

Goodwin ID, Browning SA, Anderson AJ. 2014. Climate windows for Polynesian voyaging to New Zealand and Easter Island. PNAS 111(41): 14716-14721. doi: 10.1073/pnas.1408918111.

Güttler D, Adolphi F, Beer J, Bleicher N, Boswijk G, Christl M, Hogg A, Palmer J, Vockenhuber C, Wacker L, Wunder J. 2015. Rapid increase in cosmogenic ${ }^{14} \mathrm{C}$ in $\mathrm{AD} 775$ measured in New Zealand kauri trees indicates short-lived increase in ${ }^{14} \mathrm{C}$ production spanning both hemispheres. Earth and Planetary Science Letters 411:290-297.

Haug GH, Hughen KA, Sigman DM, Peterson LC, Röhl U. 2001. Southward migration of the Intertropical Convergence Zone through the Holocene. Science 293(5533):1304-1308.

Heaton TJ, Blackwell PG, Buck CE. 2009. A Bayesian approach to the estimation of radiocarbon calibration curves: The IntCa109 methodology. Radiocarbon 51(4):1151-1164.

Heaton TJ, Blaauw M, Blackwell PG, Bronk Ramsey CB, Reimer PJ, Scott EM. 2020. The IntCal20 approach to radiocarbon calibration curve construction: a new methodology using Bayesian splines and errors-in-variables. Radiocarbon 62. This issue. doi: 10.1017/RDC.2020.46.

Hogg AG, McCormac FG, Higham TF, Reimer PJ, Baillie MG, Palmer JG. 2002. High-precision radiocarbon measurements of contemporaneous tree-ring dated wood from the British Isles and New Zealand: AD 1850-950. Radiocarbon 44(3):633-640.
Hogg A, Palmer J, Boswijk G, Turney C. 2011. Highprecision radiocarbon measurements of tree-ring dated wood from New Zealand: 195 BC-AD 995. Radiocarbon 53(3):529-542.

Hogg A, Turney C, Palmer J, Cook E, Buckley B. 2013a. Is there any evidence for regional ${ }^{14} \mathrm{C}$ offsets in the Southern Hemisphere? Radiocarbon 55(4):2029-2034.

Hogg AG, Hua Q, Blackwell PG, Niu M, Buck CE, Guilderson TP, Heaton TJ, Palmer JG, Reimer PJ, Reimer RW, Turney CS. 2013b. SHCal13 Southern Hemisphere calibration, 0-50,000 years cal BP. Radiocarbon 55(4):1889-1903.

Hogg A, Turney C, Palmer J, Southon J, Kromer B, Bronk Ramsey C, Boswijk G, Fenwick P, Noronha A, Staff R, Friedrich M. 2013c. The New Zealand kauri (Agathis australis) research project: a radiocarbon dating intercomparison of Younger Dryas wood and implications for IntCal13. Radiocarbon 55(4):2035-2048.

Hogg A, Southon J, Turney C, Palmer J, Ramsey CB, Fenwick P, Boswijk G, Büntgen U, Friedrich M, Helle G, Hughen K. 2016a. Decadally resolved lateglacial radiocarbon evidence from New Zealand kauri. Radiocarbon 58(4):709-733.

Hogg A, Southon J, Turney C, Palmer J, Bronk Ramsey C, Fenwick P, Boswijk G, Friedrich M, Helle G, Hughen K, Jones R, et al. 2016b. Punctuated shutdown of Atlantic Meridional Overturning Circulation during Greenland Stadial 1. Nature Scientific Reports 6:25902. doi: 10.1038/srep25902.

Hogg A, Gumbley W, Boswijk G, Petchey F, Southon J, Anderson A, Roa T, Donaldson L. 2017. The first accurate and precise calendar dating of New Zealand Māori Pā, using Otāhau $\mathrm{Pa}$ as a case study. Journal of Archaeological Science: Reports (12):124-133.

Hogg A, Heaton T, Bronk Ramsey C, Boswijk G, Palmer J, Turney C, Southon J, Gumbley W. 2019. The influence of calibration curve construction and composition on the accuracy and precision of radiocarbon wiggle-matching of tree rings, illustrated by Southern Hemisphere atmospheric data sets from AD 1500-1950. Radiocarbon 61:1265-1291.

Hua Q, Barbetti M, Zoppi U, Fink D, Watanasak M, Jacobsen GE. 2004a. Radiocarbon in tropical tree rings during the Little Ice Age. Nuclear Instruments and Methods in Physics Research B 223-224:489-494.

Hua Q, Barbetti M, Zoppi U. 2004b. Radiocarbon in annual tree rings from Thailand during the prebomb period, AD 1938-1954. Radiocarbon 46:925-932.

Hua Q, Barbetti M. 2007. Influence of atmospheric circulation on regional ${ }^{14} \mathrm{CO}_{2}$ differences. Journal of Geophysical Research 112:D19102. 
Hua Q, Barbetti M, Fink D, Kaiser K F, Friedrich M, Kromer B, Levchenko VA, Zoppi U, Smith AM, Bertuch F. 2009. Atmospheric ${ }^{14} \mathrm{C}$ variations derived from tree rings during the early Younger Dryas. Quaternary Science Reviews 28(25): 2982-2990.

Hua Q, Barbetti M, Levchenko VA, D'Arrigo RD, Buckley BM, Smith AM. 2012. Monsoonal influence on Southern Hemisphere ${ }^{14} \mathrm{CO}_{2}$. Geophysical Research Letters 39:L19806.

Lerman JC, Mook WG, Vogel JC, de Waard H. 1969. Carbon-14 in Patagonian tree rings. Science 165:1123-1124.

Lerman JC, Mook WG, Vogel JC. 1970. C14 in tree rings from different localities. In: Olsson IU, editor. Radiocarbon variations and Absolute Chronology. New York: Wiley. p. 275-301.

Marsh EJ, Bruno MC, Fritz SC, Baker P, Capriles JM, Hastorf CA. 2018. IntCal, SHCal, or a mixed curve? Choosing a ${ }^{14} \mathrm{C}$ calibration curve for archaeological and paleoenvironmental records from Tropical South America. Radiocarbon 60:925-940.

McCormac FG, Hogg AG, Higham TF, Baillie MG, Palmer JG, Xiong L, Pilcher JR, Brown DS, Hoper ST. 1998a. Variations of radiocarbon in tree rings: Southern Hemisphere offset preliminary results. Radiocarbon 40(3):1153-1159.

McCormac FG, Hogg AG, Higham TF, Lynch Stieglitz J, Broecker WS, Baillie MG, Palmer JG, Xiong L, Pilcher JR, Brown DS, Hoper ST. 1998b. Temporal variation in the interhemispheric ${ }^{14} \mathrm{C}$ offset. Geophysical Research Letters 25(9): 1321-1324.

McCormac FG, Reimer PJ, Hogg AG, Higham TFG, Baillie MGL, Palmer J, Stuiver M. 2002. Calibration of the radiocarbon time scale for the southern hemisphere: AD 1850-950. Radiocarbon 44:641-651.

McCormac FG, Hogg AG, Blackwell PG, Buck CE, Higham TFG, Reimer PJ. 2004. SHCal04 2004 Southern Hemisphere calibration, 0-11.0 cal kyr BP. Radiocarbon 46(3):1087-1092.

McGregor GR, Nieuwolt S. 1998. Tropical climatology - an introduction to the climates of the low latitudes. Hoboken: John Wiley.

Mekhaldi F, Muscheler R, Adolphi F, Aldahan A, Beer J, McConnell JR, Possnert G, Sigl M, Svensson A, Synal H-A, Welten KC, Woodruff TE. 2015. Multiradionuclide evidence for the solar origin of the cosmic-ray events of AD 774/5 and 993/4. Nature Communications 6:8611. doi: 10.1038/ncomms9611.

Miyake F, Nagaya K, Masuda K, Nakamura T. 2012. A signature of cosmic-ray increase in AD 774-775 from tree rings in Japan. Nature 486:240-2.

Miyake F, Masuda K, Nakamura T. 2013. Another rapid event in the carbon-14 content of tree rings. Nature Communications 4:1748. doi: 10 . 1038/ncomms2783.
Niu M, Heaton TJ, Blackwell PG, Buck CE. 2013. The bayesian approach to radiocarbon calibration curve estimation: The IntCal13, Marine13, and SHCal13 methodologies. Radiocarbon 55(4): 1905-1922.

Palmer JG, Turney CS, Cook ER, Fenwick P, Thomas Z, Helle G, Jones R, Clement A, Hogg A, Southon J, Bronk Ramsey C. 2016. Changes in El Niño-Southern Oscillation (ENSO) conditions during the Greenland Stadial 1 (GS-1) chronozone revealed by New Zealand tree rings. Quaternary Science Reviews 153:139-155.

Pearson C, Wacker L, Bayliss A, Brown D, Salzer M, Brewer P, Bollhalder S, Boswijk G, Hodgins G. 2020. Annual variation in atmospheric ${ }^{14} \mathrm{C}$ between $1700 \mathrm{BC}$ and $1480 \mathrm{BC}$. Radiocarbon 62. This issue. doi: 10.1017/RDC.2020.14.

Reimer PJ, Baillie MG, Bard E, Bayliss A, Beck JW, Bertrand C, Blackwell PG, Buck CE, Burr G, Cutler KB, et al. 2004. IntCal04 Atmospheric radiocarbon age calibration, 26-0 ka BP. Radiocarbon 46:1029-1058.

Reimer, P, Bard E, Bayliss A, Beck W, Blackwell P, Bronk Ramsey C, Buck C, Cheng H, Edwards L, Friedrich M, et al. 2013. IntCal13 and Marine13 radiocarbon age calibration curves $0-50,000$ years cal BP. Radiocarbon 55(4):1869-1887.

Reimer PJ, Austin WEN, Bard E, Bayliss A, Blackwell PG, Ramsey CB, Butzin M, Cheng H, Edwards RL, Friedrich M, et al. 2020. The IntCal20 Northern Hemisphere radiocarbon calibration curve (0-55 cal kBP). Radiocarbon 62. This issue. doi: $10.1017 /$ RDC.2020.41.

Rodgers KB, Mikaloff-Fletcher SE, Bianchi D, Beaulieu C, Galbraith ED, Gnanadesikan A, Hogg AG, Iudicone D, Lintner BR, Naegler T, Reimer PJ. 2011. Interhemispheric gradient of atmospheric radiocarbon reveals natural variability of Southern Ocean winds. Climate of the Past 7:1123-1138.

Scott EM, Cook GT, Naysmith P. 2017. Should archaeologists care about ${ }^{14} \mathrm{C}$ intercomparisons? Why? A summary report on SIRI Radiocarbon 59(5):1589-1596.

Sookdeo A, Kromer B, Buentgen U, Friedrich M, Friedrich R, Helle G, Pauly M, Nievergelt D, Reinig F, Treydte K, Synal H-A, Wacker L. 2019. Quality dating: A well-defined protocol implemented at ETH Zurich for high-precision ${ }^{14} \mathrm{C}$ dates tested on Late Glacial wood. Radiocarbon 62. This issue. doi: 10.1017/RDC. 2019.132.

Sookdeo A, Kromer B, Adolphi F, Beer J, Brehm N, Büntgen U, Christl M, Eglinton T, Friedrich M, Guidobaldi G, Helle G, Muscheler R, Nievergelt D, Pauly M, Reinig F, Tegel W, Treydte K, Turney CSM, Synal H-A, Wacker L. 2020. Tree-ring radiocarbon reveals reduced solar activity during Younger Dryas cooling. Submitted to Nature Geoscience. 
Stuiver M, Pearson GW. 1993. High-precision calibration of the radiocarbon time scale, AD 1950-500 BC and 2500-6000 BC. Radiocarbon 35(1): $1-23$

Stuiver M, Reimer PJ, Bard E, Beck JW, Burr GS, Hughen KA, Kromer B, McCormac G, van der Plicht J, Spurk M. 1998. INTCAL98 radiocarbon age calibration, 24,000-0 cal BP. Radiocarbon 40(3): 1041-1083.

Stuiver M, Braziunas TF. 1998. Anthropogenic and solar components of hemispheric ${ }^{14} \mathrm{C}$. Geophysical Research Letters 25(3):329-332.

Stuiver M, Reimer PJ, Reimer RW. 2020. CALIB 8.2 [WWW program] available at http://calib.org.

Turney CS, Palmer J, Hogg A, Fogwill CJ, Jones RT, Bronk Ramsey C, Fenwick P, Grierson P, Wilmshurst J, O'Donnell A, Thomas ZA. 2016. Multidecadal variations in Southern Hemisphere atmospheric ${ }^{14} \mathrm{C}$ : Evidence against a Southern Ocean sink at the end of the Little Ice Age $\mathrm{CO}_{2}$ anomaly. Global Biogeochemical Cycles 30(2): 211-218.

Vogel JC, Fuls A, Visser E, Becker B. 1986. Radiocarbon fluctuations during the third millennium BC. Radiocarbon 28(2B):935-938.

Vogel JC, Fuls A, Visser E, Becker B. 1993. Pretoria calibration curve for short-lived samples 19303350 BC. Radiocarbon 35(1):73-85.

Xie P, Arkin PA. 1997. Global precipitation: a 17-year monthly analysis based on gauge observations, satellite estimates, and numerical model outputs. Bulletin of the American Meteorological Society 78:2539-2558.

Zhang S, Wang B. 2008. Global summer monsoon rainy seasons. International Journal of Climatology 28:1563-1578.

Zimmerman S, Guilderson T, Buckley B, Cook E. 2010. Extension of the Southern Hemisphere atmospheric radiocarbon curve, 2120-850 years BP: Results from Tasmanian Huon pine. Radiocarbon 52(2-3):887-894. 